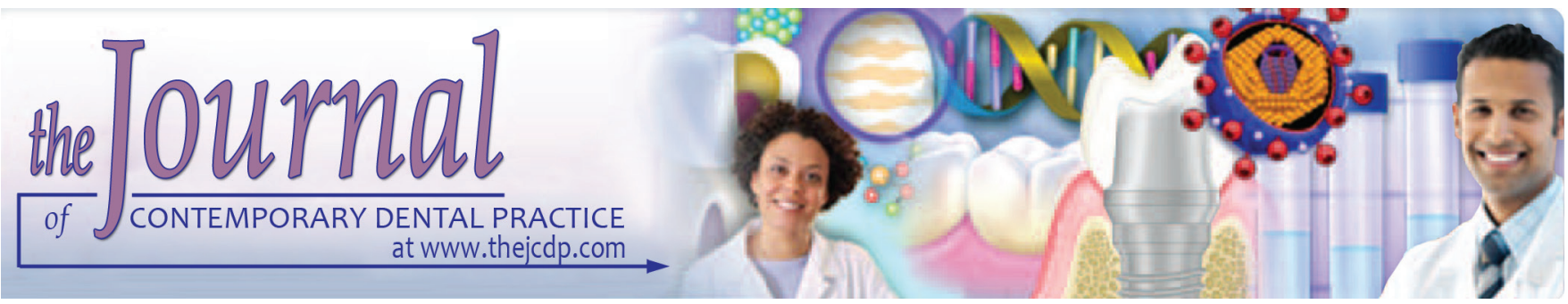

\title{
Effectiveness of Roselle Effervescent Tablets as Traditional Medicinal Plants in preventing Growth of Candida albicans Colonies and Streptococcus mutans
}

Edy Machmud

\begin{abstract}
Aim: To analyze the effectiveness of roselle effervescent tablets inhibiting the growth of Streptococcus mutans and Candida albicans colonies on acrylic resin plate.
\end{abstract}

Materials and methods: A total of 90 plates of acrylic resin with S. mutans and $C$. albicans suspensions were divided into three groups of immersion: The first group was soaked in a solution of roselle effervescent tablets $10 \%$, the second group soaked in solution of sodium perborate effervescent tablets, and the third group soaked in a solution of pure effervescent tablets each with an interval of 5,10, and 15 minutes. The number of colonies of $S$. mutans and $C$. albicans was calculated before and after immersion to determine the effectiveness of effervescent tablets. Data were analyzed using t-test and one-way analysis of variance (ANOVA).

Results: The roselle effervescent tablets $10 \%$ showed a significant difference before and after immersion, thus inhibiting the growth of $S$. mutans and $C$. albicans colonies $(p<0.05)$. Roselle effervescent tablets $10 \%$ in immersion time 5, 10, and 15 minutes did not show any significant difference. The effectiveness of roselle effervescent tablets $10 \%$ did not show any significant differences with sodium perborate effervescent tablets.

Conclusion: Roselle effervescent tablets are effective in preventing $S$. mutans and $C$. albicans colonies like effectiveness with sodium perborate effervescent tablets.

Clinical significance: Roselle effervescent tablets 10\% are effective in inhibiting the $S$. mutans and $C$. albicans colonies with immersion time of 5 minutes and have the same effectiveness with sodium perborate effervescent tablets.

Keywords: Candida albicans, Roselle effervescent tablets, Streptococcus mutans.

Department of Prosthetic Dentistry, Hasanuddin University Makassar, Indonesia

Corresponding Author: Edy Machmud, Department of Prosthetic Dentistry, Hasanuddin University, Makassar Indonesia, Phone: +62411586012, e-mail: andimuamarq@ yahoo.com
How to cite this article: Machmud E. Effectiveness of Roselle Effervescent Tablets as Traditional Medicinal Plants in preventing Growth of Candida albicans Colonies and Streptococcus mutans. J Contemp Dent Pract 2018;19(8):925-928.

Source of support: Nil

Conflict of interest: None

\section{INTRODUCTION}

Traditional plants with potential therapeutics have been used from time immemorial to cure various aliment and infection diseases. ${ }^{1}$ Bioactive compound present in Hibiscus sabdariffa L (roselle) has been reported to be accountable for various observed biological activities. ${ }^{1,2}$ The study of Alaga et $\mathrm{al}^{3}$ stated that roselle flower extract contains bioactive compounds, such as saponins, alcoloid, tannin, phenol, glycoside, and flavonoid. Of late, scientific evidence has been provided on the potential antimicrobial activities of bioactive compounds by traditionally used roselle flower extract. ${ }^{1}$ This is evident from research by Ratnasari et $\mathrm{al}^{4}{ }^{4}$ which states that roselle flowers infusion has effect on inhibition of $C$. albicans colonization on acrylic resin.

Polymethyl methacrylate or acrylic resin has been successfully used for fabricating denture base. Unfortunately, acrylic has some disadvantages, particularly its microscopic and microporosity on the surface of the acrylic material. This leads to the accumulation of plaque and bacteria that will increase the colonies of bacteria and fungi in a long time and can lead to denture stomatitis with formation of biofilm. ${ }^{5,6}$ Ribeiro et al reported C. albicans were the most frequent microorganisms found in dentures (65\%), while S. mutans and Streptococcus aureus were present in 53.3 and $34.4 \%$ respectively. ${ }^{7}$

Prevention of denture stomatitis is to maintain oral hygiene and dental hygiene of denture from fungi and 
bacterial contamination. Denture cleansers can use either mechanical or chemical methods. ${ }^{8}$ Cleaning by chemical method consists of immersion of the denture in disinfectant solution and mechanical method by brushing or ultrasonic devices. ${ }^{6,9}$ Cleaning acrylic resin denture chemically is more effective than mechanical. So it needs cleaning materials that have a bactericide and fungicide, is easy to use, and is compatible with material denture.

To inhibit plaque formation on denture base in the field of dentistry, research is to be conducted using disinfectant solution packaged in effervescent tablet form with $H$. sabdariffa L. (roselle) flower extract. Effervescence is a reaction between citric acid compound with alkaline carbonate or bicarbonate. ${ }^{10}$ When dissolved in water, there is emission of gas, thereby allowing mechanical cleaning with gas bubbles as well as chemical cleaning by citric acid and other substances. ${ }^{11,12}$ In addition, the use of effervescent tablet is considered more convenient because it does not require a large container to store, with size and appropriate dosage. ${ }^{10}$

Based on this background, this study was conducted to analyze the effectiveness and determine immersion time of the use of roselle effervescent tablets in inhibiting the formation of C. albicans and S. mutans colonies on acrylic resin plate.

\section{MATERIALS AND METHODS}

This study is an experimental research study (in situ) conducted at the Laboratory of Microbiology, University of Airlangga, using 10\% roselle effervescent tablet, sodium perborate effervescent tablet found in the market (positive control), and pure effervescent tablet without the active substance of sodium perborate or roselle (negative control) with immersion time of 5, 10, and 15 minutes. The sample used is acrylic resin plate made of heat curing acrylic material with a size of $65 \times 10 \times$ $2.5 \mathrm{~mm}$ made in Asia Africa Laboratory, Bandung, with as many as 90 plates.

\section{Manufacturing of $10 \%$ Roselle Extract}

One hundred grams of dried roselle flower petals was mixed with hot water at $80^{\circ} \mathrm{C}$ which was then filtered, forming $10 \%$ roselle filtrate. Roselle filtrate was mixed with $50 \%$ dextrin and dried under $60^{\circ} \mathrm{C}$ vacuum for 8 hours, which resulted in $10 \%$ roselle extract.

\section{Manufacturing of $10 \%$ Roselle Effervescent Tablet}

Roselle effervescent tablet is made by mixing $10 \%$ roselle extract with $16 \%$ citric acid and $16 \%$ sodium bicarbonate for 2 minutes and then sieving 60 meshes and making the tablets.

\section{Measurement of S. mutans and $\boldsymbol{C}$. albicans}

The number of S. mutans and C. albicans colonies was measured before and after immersing in effervescent tablet on $65 \times 10 \times 2.5 \mathrm{~mm}$ acrylic resin plate with the following procedures: Acrylic resin plate that has been sterilized in an autoclave at $121^{\circ} \mathrm{C}$ is inserted into the suspension of S. mutans or C. albicans and incubated for 24 hours at $37^{\circ} \mathrm{C}$. The plates were rinsed with phosphate-buffered saline, then put in $10 \mathrm{~mL}$ brain heart infusion (BHI) broth or Sabouraud's broth and vibrated with vibrator for 30 seconds to produce a suspension of $S$. mutans and C. albicans. The suspension was taken using a 1 cc tuberculin syringe and incubated at tryptone, yeast extract, cystine (TYC) agar or Sabouraud's dextrose agar for 48 hours at $37^{\circ} \mathrm{C}$ (pretest). The plates are then immersed in $10 \%$ roselle effervescent tablet solution for 5, 10, and 15 minutes and then put into $10 \mathrm{~mL}$ BHI broth or Sabouraud's broth and vibrated with a vibrator for 30 seconds. The suspension was taken using a 1 cc tuberculin syringe and incubated at TYC agar or Sabouraud's dextrose agar for 48 hours at $37^{\circ} \mathrm{C}$ (posttest). Measurement of the effectiveness of S. mutans or C. albicans colonies was done by comparing the number of colonies pretest and posttest using a counter and expressed in colony-forming units $/ \mathrm{mL}$.

\section{Data Analysis}

This study using a one-way ANOVA test and Statistical Package for the Social Sciences version 20.0 (SPSS Inc., Chicago, Illinois, USA).

\section{RESULTS}

Effects of $10 \%$ roselle effervescent tablet solution immersion time against its effectiveness in inhibiting the number of $S$. mutans and C. albicans colonies on acrylic resin plate looks:

The results of the study (Table 1) showed no significant difference between the effectiveness of immersion times of 5,10 , and 15 minutes in the immersion group of $10 \%$ roselle effervescent tablet and sodium perborate effervescent tablet against its effectiveness in inhibiting the S. mutans and C. albicans colonies, whereas the immersing group with pure effervescent tablet showed significant differences in effectiveness between the immersion times of 5,10 , and 15 minutes.

\section{DISCUSSION}

This study used effervescent tablet made from extracts of roselle flower petals with a concentration of $10 \%$ of sodium perborate effervescent tablet which is in a package, and pure effervescent tablet without additional 
Effectiveness of Roselle Effervescent Tablets as Traditional Medicinal Plants

Table 1: Difference of the effectiveness of immersion groups to the number of $C$. albicans and $S$. mutans colonies by the time of immersion

\begin{tabular}{|c|c|c|c|c|c|}
\hline \multirow[b]{3}{*}{ Microorganisms } & \multirow[b]{3}{*}{ Immersion group } & \multicolumn{3}{|c|}{ Effectiveness based on time } & \multirow[b]{3}{*}{$p$-value } \\
\hline & & 5 minutes & 10 minutes & 15 minutes & \\
\hline & & Mean $\pm S D$ & Mean $\pm S D$ & Mean $\pm S D$ & \\
\hline \multirow[t]{4}{*}{ S. mutans } & $10 \%$ roselle effervescent tablet & $106.00 \pm 1.00$ & $106.40 \pm 2.41$ & $107.07 \pm 2.40$ & 0.135 \\
\hline & Sodium perborate effervescent tablet & $107.20 \pm 1.30$ & $107.80 \pm 1.79$ & $109.20 \pm 1.30$ & 0.133 \\
\hline & Pure effervescent tablet (control) & $64.00 \pm 3.40$ & $71.60 \pm 2.97$ & $80.00 \pm 2.92$ & $0.000^{*}$ \\
\hline & $10 \%$ roselle effervescent tablet & $102.60 \pm 2.19$ & $104.40 \pm 2.51$ & $104.60 \pm 2.79$ & 0.409 \\
\hline \multirow[t]{2}{*}{ C. albicans } & Sodium perborate effervescent tablet & $104.60 \pm 2.07$ & $106.80 \pm 1.79$ & $106.80 \pm 1.92$ & 0.158 \\
\hline & Pure effervescent tablet (control) & $45.00 \pm 2.45$ & $56.60 \pm 3.58$ & $65.60 \pm 3.51$ & $0.000^{*}$ \\
\hline
\end{tabular}

Normality test, Shapiro-Wilk test: $p>0.05$; normal distribution of data; ${ }^{*}$ One way ANOVA test: $p<0.05$; significant

extract of roselle flower petals or sodium perborate. Effervescent tablets are made from a mixture of sodium bicarbonate and citric acid or tartaric acid and is classified as a chemical-bath-type material (chemical soak). ${ }^{11}$

Effervescent sodium perborate and roselle 10\% showed no significant difference on immersion of 5,10 , and 15 minutes on the effectiveness of $10 \%$ roselle effervescent tablet solution in the number of $C$. albicans and S. mutans colonies (Table 1). This means that the immersion time of 5 minutes gives meaningful results on the effectiveness $10 \%$ roselle effervescent tablet solution to inhibit the number of S. mutans and C. albicans colonies. This is consistent with the study of Ganesh et $\mathrm{al}^{13}$ who state that several disinfectants showed the effectiveness of antimicrobial with a vulnerable time of 4 to 8 minutes. Yildirim-Bicer et al $^{14}$ also said that the 5-minute immersion of acrylic resin plate effervescent in a hydrogen peroxide solution is effective as immersion acrylic resin plate for 30 minutes. This approaches immersion protocol of effervescent dental cleanser at $50^{\circ} \mathrm{C}$ for 3 minutes twice a day. According to Lee ${ }^{15}$ the effervescent is resolved when dispersed well with time $\leq 5$ minutes. ${ }^{16}$

This study showed after immersion of $10 \%$ roselle effervescent tablet, sodium perborate effervescent tablet and pure effervescent tablet without the active substance sodium and roselle, seen in inhibiting the number of S. mutans and C. albicans colonies on acrylic resin plate. This is supported by the research of Desrosiers et $\mathrm{al}^{17}$ which states that some types of denture cleanser containing citric acid are chemotherapeutic agents that can effectively interfere with bacterial biofilm matrix by inhibiting calcium ions, resulting in antibioflim activity. Ntrouka et $\mathrm{al}^{18}$ study that assessed the ability of citric acid solution given on the surface of the implant showed a decrease in the number of pathogenic species, especially the species of $S$. mutans bacteria. Izumi et a $1^{19}$ study revealed that denture cleansers using organic acids showed a decrease in the number of species of Streptococcus sanguinis, Streptococcus pneumoniae, C. albicans and their effects are strong as commercial denture cleansers and safe to use by old people. Faot et $\mathrm{al}^{20}$ stated that denture cleanser citric acid has effect in inhibiting C. albicans after treatment but cannot eliminate the biofilm as a whole. Roselle effervescent tablets $10 \%$ proved to reduce the number of bacterial and fungal colonies due to the content of polyphenols. A study conducted by Sayagoayerdi et $\mathrm{al}^{21}$ showed that $66 \%$ of the polyphenol content contained in the roselle flower is polyphenol. Research conducted by Nurkhasanah et $\mathrm{al}^{22}$ proved that the flavonoid contained in the plant roselle is one of many groups of active substances. Flavonoids work by denaturing proteins and increasing the permeability of cell membranes. ${ }^{23}$ The function of the disrupted cell membrane can cause disruption in cell formation, resulting in cellular damage to Candida and Streptococcus bacteria. The damage causes the death of $C$. albicans and Streptococcus bacteria, according to Jawetz ${ }^{24}$ study. Polyphenol compounds decrease bacterial activity so that it indirectly influences inhibition of activity of colony formation of bacteria and fungi on denture plate. ${ }^{25}$

\section{CONCLUSION}

Roselle effervescent tablets 10\% are effective in inhibiting C. albicans and S. mutans colonies with immersion time of 5 minutes and have the same effectiveness with sodium perborate effervescent tablet.

\section{REFERENCES}

1. Voon HC, Baht R, Rusul G. Flower extracts and their essential oils as potential antimicrobial agents for food uses and pharmaceutical applications. Compr Rev Food Sci Food Saf 2012;11(1).

2. Pacome OB, Bernard DN, Sekau D, Joseph DA, David NJ, Mangomoke K, Hilaire KT. Phytochemical and antioxidant activity of Roselle (Hibiscus Sabdariffa L.) petal extracts. Res J Pharm Biol Chem Sci 2014;5(2):1453.

3. Alaga TO, Edema MO, Atayase AO, Bankole MO. Phytochemical and in vitro anti-bacterial properties of hibiscus sabdariffa L (Roselle) juice. J Med Plant Res 2014;8(6):339-344.

4. Ratnasari A, Widajati $W$, Hendrijantini N. The effect of rosella flower infusion in inhibiting Candida albicans colonization on acrylic resin. J Prosthod 2013;4(1):22-26. 
5. Rathee M, Hooda A, Ghalaut P. Denture hygiene in geriatric persons. J Geriatr Gerontol 2010;6(1):8-15.

6. Andrade IM, Cruz PC, Silva CH, Souza RF, Paranhos HF, Candido RC, Marin JM, de Souza-Gugelmin MC. Effervescent tablets and ultrasonic devices against Candida and mutans streptococci in denture biofilms. Gerodontology 2011 Dec;28(4): 264-270.

7. Ribeiro DG, Pavarina AC, Dovigo LN, Machado AL, Giampaolo ET, Verdant CE. Prevalence of Candida spp. associated with bacteria species on complete dentures. Gerodontology 2012 Sep;29(3):203-208.

8. de Souza RF, Paranhos HF, da Silva CH, Abu-Naba'a L, Fedorowicz Z, Gurgan CA. Interventions for complete denture cleaning in adults. Cochrane Database Syst Rev 2009 Oct 7;(4):CD007395.

9. Piranhas HF, Silva $\mathrm{CH}$, Souza RF, Crush PC, Freitas KM, Peracini A. Effects of mechanical and chemical method on denture biofilm accumulation. J Oral Rehabil 2007 Aug;34(8): 606-612.

10. Sataphaty SR, Patra M, Patnaik M. Process and variation effervescent formulation review. Innovat Int J Med Pharm Sci 2016;1(1).

11. Vieria AP, Senna PM, Silva WJ, Cury AA. Long-term efficacy of denture cleansers in preventing Candida spp. biofilm recolonization on liner surface. Braz Oral Res 2010;24(3):342-348.

12. PorciniA,DaviLR, RibeiroNQ, Souza RF, Silva CH,ParanhosHO. Effect of denture cleansers on physical properties of heatpolymerized acrylic resin. J Prosthodont Res 2010 Apr;54(2): 78-83.

13. Ganesh S, Gujiari AK, Kumar BS. Comparative study to access the effectiveness of various disinfectants on two microorganisms and the effect of same on flexural strength of acrylic denture base resin an in vitro study. J Int Oral Health 2013;5(3):55-62.

14. Yildirim-Bicer AZ, Peker I, Akca G, Celik I. In vitro antifungal evaluation of seven different disinfectants on acrylic resins. Biomed Res Int 2014;2014:519098.
15. Lee RE. Key facts about a unique dosage form effervescent tablet. Amerinlab Technologies; 2004.

16. Shinawi L. The effect of various denture cleansers on the colour stability of different denture base resins. Int J Pharm Res 2017;6(2):238-246.

17. Desrosiers M, Myntti M, James G. Methods for removing bacterial biofilms in vitro study using clinical chronic rhino sinusitis specimens. Am J Rhinol 2007;21:527-532.

18. Ntrouka V, Hoogenkamp M, Zaura E, Van der Weijden F. The effect of chemotherapeutic agents on titanium-adherent biofilms. Clin Oral Implants Res 2011 Nov;22(11):1227-1234.

19. Izumi S, Ryu M, Ueda T, Ishihara K, Sakurai K. Evaluation of application possibility of water containing organic acids for chemical denture cleaning for older adults. Geriatr Gerontol Int 2016;16(3):300-306.

20. Faot F, Cavalcanti YW, Bertolini MM, Pinto LR, Silva WJ, Cury AA. Efficacy of citric acid denture cleanser on the Candida albicans biofilm formed on polymethyl methacrylate: effects on residual biofilm and recolonization process. BMC Oral Health 2014 Jun 23;14(77):1-7.

21. Sayago-ayerdi SG, Arranz S, Serrano J, Goni I. Dietary fiber content and associated antioxidant compounds in Roselle flower (Hibiscus sabdariffa L.) beverage. J Agric Food Chemo 2007 Sep 19;55(19):7886-7890.

22. Nurkhasanah, Yuwono T, Nurani LH, Rizki MI, Kraisintu K. The development of chitosan nanoparticles from hibiscus sabdariffa calyx extract from Indonesia and Thailand. Int J Pharm Sci Res 2015;6(5):1855-1861.

23. Grotewold E. The science of flavonoids. New York: Springer Publishers; 2006. pp. 1-280.

24. Jawetz EM. Review of medical microbiology. 16th ed. San Fransisco: Longo Medical Pub; 1986. pp. 143-148, 297-299.

25. Goyal P, Anggarwal BK. A study on combinatorial effects of various flavonoids for their antibacterial potential against clinically significant bacterial species. Hacettepe J Biol Chem 2010;38(4):255-258. 